\title{
Racial and Ethnic Differences in Connectedness to Nature and Landscape Preferences Among College Students
}

\author{
Dorceta E. Taylor
}

\begin{abstract}
An extensive body of environmental psychology, outdoor recreation, and landscape preference research reports that blacks are alienated from nature, fearful of it, and prefer urbanized and developed landscapes to wild or natural environments. But, are these responses and preferences as widespread as reported? Most of the studies in these genres focus on black-white differences. This article provides a more complex analysis by incorporating an environmental justice framework in the assessment of the ways in which blacks, whites, and other minority college students reflect on and think about nature. It also examines how they perceive their connectedness to nature, their curiosity about nature, and their landscape preferences. The participants are students taking part in science, technology, engineering, and mathematics programming at a large public midwestern university, a mid-sized private university in the mid-Atlantic region, and a small historically black university in the deep south. The sample of 157 participants contains 46 whites, 43 blacks, and 68 other minorities. None of the respondents say they are disconnected from nature. Most say that, first and foremost, they think about trees, forests, and plants when they think of nature. The study found that black students prefer naturalistic landscapes more than urbanized settings and their perceptions of nature and landscapes mirror that of students of other racial and ethnic groups. None of the study respondents reported a generalized fear of nature either. Instead, students expressed situational fear, object-specific dislike, and simultaneous contradictions when viewing landscape images.
\end{abstract}

Keywords: natural, built, environment, white, black, minority, outdoor recreation, scenery, fear

\section{INTRODUCTION}

$\mathbf{E}$ ARLY CONCEPTIONS OF WILDLANDS CHARACTERIZE these landscapes as loathsome, repulsive, and evil abodes that most humans fear and avoid. However, since the eighteenth century, outdoor enthusiasts have extolled the virtues of nature and wild landscapes. They argue that such landscapes are refuges that invigorate inhabitants and improve human health and well-being. The wilds are

Prof. Dorceta E. Taylor is a professor at the School for the Environment and Sustainability, University of Michigan, Ann Arbor, Michigan.

(C) Taylor, 2018; Published by Mary Ann Liebert, Inc. This Open Access article is distributed under the terms of the Creative Commons Attribution Noncommercial License (http:// creativecommons.org/licenses/by-nc/4.0/) which permits any noncommercial use, distribution, and reproduction in any medium, provided the original author(s) and the source are credited. also portrayed as the antithesis of the depravity associated with cities. ${ }^{1,2,3,4,5}$ Some scholars argue that despite the changing perceptions of nature and wilderness, wildlands are not universally perceived as nurturing or

\footnotetext{
${ }^{1}$ Roderick Nash. Wilderness and the American Mind, 3rd ed. (Yale University Press, 1982).

${ }^{2}$ Max Oelschlaeger. The Idea of Wilderness. (Yale University Press, 1991).

${ }^{3}$ Dorceta E. Taylor. The Rise of the American Conservation Movement: Power, Privilege, and Environmental Protection. (Duke University Press, 2016).

${ }^{4}$ Dorceta E. Taylor. The Environment and the People in American Cities, 1600s-1900s: Disorder, Inequality, and Social Change. (Duke University Press, 2009).

${ }^{5}$ Agnes E. Van den Berg and Sander L. Koole. "New Wilderness in the Netherlands: An Investigation of Visual Preferences for Nature Development Landscapes." Landscape and Urban Planning 78 (2006): 362-372.
} 
safe spaces. That is, there are people who dislike and fear them and prefer not to interact with them. ${ }^{6,7,8,9,10,11}$

Interest in nature and wild landscapes continues and contemporary scholars, planners, resource managers, and environmental activists are still concerned with and intrigued by the way people perceive nature. They are also intrigued by the landscapes people are attracted to or repelled by. This has resulted in a substantial body of research suggesting that interactions with nature are related to connectedness to nature and proenvironmental behaviors, ${ }^{12,13,14}$ as well as restoration and psychological well-being. $^{15,16,17,18,19}$

This article summarizes the findings of two bodies of research that have probed this topic: environmental psychology and outdoor recreation/landscape preferences. It identifies shortcomings in the way researchers have interpreted findings about racial and ethnic minorities and their connectedness to nature and different types of landscapes. The article incorporates environmental justice (EJ) approaches into the study of people's connection to nature and landscapes. It presents the results of

\footnotetext{
${ }^{6}$ Robert D. Bixler, Cynthia L. Carlisle, William E. Hammitt, and Myron F. Floyd. "Observed Fears and Discomforts among Urban Students on Field Trips to Wildland Areas." The Journal of Environmental Education 26 (2004): 24-33.

${ }^{7}$ Robert D. Bixler and Myron F. Floyd. "Nature is Scary, Disgusting, and Uncomfortable." Environment and Behavior 29 (1997): 443-467.

${ }^{8}$ Alec Brownlow. "An Archeology of Fear and Environ-
} mental Change in Philadelphia." Geoforum 36 (2006): 227-245.

${ }^{9}$ Paul H. Gobster. "Managing Urban Parks for a Racially and Ethnically Diverse Clientele." Leisure Sciences 24 (2002): 143159.

${ }_{10}$ James G. Lewis and Robert Hendricks. "A Brief History of African Americans and Forests." Unpublished collaboration between the Forest History Society and the USDA Forest Service. (2006). <https://www.fs.fed.us/people/aasg/PDFs/African_ Americans_and_forests_March21\%202006.pdf>.

${ }^{11}$ Herbert W. Schroeder. "Perceptions and Preferences of Urban Forest Users." Journal of Arboriculture 16 (1990): 58-61.

${ }^{12}$ Thomas H. Beery and Daniel Wolf-Watz. "Nature to Place: Rethinking the Environmental Connectedness Perspective." Journal of Environmental Psychology 40 (2014): 198-205.

${ }^{13}$ Lissy Goralnik and Michael P. Nelson. "Framing a Philosophy of Environmental Action: Aldo Leopold, John Muir, and the Importance of Community." Journal of Environmental Education 42 (2011): 181-192.

${ }^{14}$ Elizabeth Nisbet, John M. Zelenski, and Steven A. Murphy. "Happiness is in Our Nature: Exploring Nature Relatedness as a Contributor to Subjective Wellbeing." Journal of Happiness Studies 12 (2011): 303-322.

${ }^{15}$ Colin A. Capaldi, Raelyne L. Dopko, and John M, Zelenski. "The Relationship Between Nature Connectedness and Happiness: A Meta-Analysis." Frontiers in Psychology 5 (2014): 976-990.

${ }^{16}$ Stephen Kaplan. "The Restorative Benefits of Nature: Toward an Integrative Framework." Journal of Environmental Psychology 15 (1995): 169-182.

${ }^{17}$ Schroeder (1990), Op. cit.

${ }^{18}$ Herbert W. Schroeder. "Esthetic Perceptions of the Urban Forest: A Utility Perspective." Journal of Arboriculture 15 (1989): 292-294.

${ }^{19}$ Agnes E. Van den Berg, Sander L. Koole, and Nickie Y. van der Wulp. "Environmental Preference and Restoration: (How) are They Related?" Journal of Environmental Psychology 23 (2003): 135-146. a study that examines four factors: racial and ethnic differences in (1) the way college students perceive nature, (2) the extent of their connectedness to nature, (3) their curiosity about nature, and (4) their level of affinity toward eight different types of landscapes. The essay studies college students - an important, but understudied, segment of the population. This article challenges the notion that some racial and ethnic groups are predisposed to fear nature and are, therefore, repelled by it.

\section{Environmental psychology and the analysis of race/ethnicity and connection to nature}

Wilson's ${ }^{20,21}$ biophilia hypothesis asserts that humans have an innate connection to nature. Adherents of this thesis contend that the human-nature connection is mediated by values and those values are rooted in biology or our evolutionary past. $^{22,23,24,25,26,27}$ This has led some researchers to attempt to measure people's emotional connection or kinship to the natural world. ${ }^{28,29,30}$ Mayer and Frant $z^{31}$ and Pereira and Forster ${ }^{32}$ argue further that connectedness to nature is a strong predictor of ecological

${ }^{20}$ Edward O. Wilson. "Biophilia and the Conservation Ethic." In: Stephen R. Kellert and Edward O. Wilson, eds. The Biophilia Hypothesis. (Island Press, 1993), 31-41.

${ }^{21}$ Edward O. Wilson. Biophilia: The Human Bond with Other Species. (Harvard University Press, 1984).

${ }^{22}$ Stephen Kaplan. "Environmental Preference in KnowledgeSeeking, Knowledge-Using Organism." In: Jerome H. Barkow, Leda Cosmides, and John Tooby, eds. The Adapted Mind: Evolutionary Psychology and the Generation of Culture. (Oxford University Press, 1992), 581-598.

${ }^{23}$ Stephen R. Kellert. "The Biological Basis for Human Values of Nature.' In: Stephen R. Kellert and Edward O. Wilson, eds. The Biophilia Hypothesis. (Island Press, 1993), 42-72.

${ }^{24}$ Ibid.

${ }^{25}$ F. Stephan Mayer, Cynthia M. Frantz, Emma BruehlmanSenecal, and Kiffin Dolliver. "Why is Nature Beneficial? The Role of Connectedness to Nature." Environment and Behavior 41 (2009): 607-643.

${ }^{26}$ Roger S. Ulrich. "Biophilic Theory and Research for Healthcare Design." In: Stephen R. Kellert, Judith H. Heerwagen, and Martin L. Mador, eds. Biophilic Design: The Theory, Science, and Practice of Bringing Building to Life. (John Wiley, 2008), 27-86.

${ }^{27}$ Roger S. Ulrich. "Biophilia, Biophobia, and Natural Landscapes." In: Stephen R. Kellert and Edward O. Wilson, eds. Biophilia Hypothesis. (Island Press, 1993), 73-137.

${ }^{28}$ F. Stephan Mayer and Cynthia M. Frantz. "The Connectedness to Nature Scale: A Measure of Individuals' Feeling in Community with Nature." Journal of Environmental Psychology 24 (2004): 503-515.

${ }^{29}$ Pablo Olivos, Juan I. Aragonés, and María Amérigo. "The Connectedness to Nature Scale and Its Relationship with Environmental Beliefs and Identity." International Journal of Hispanic Psychology 4 (2011): 5-19.

${ }^{30}$ Jeffrey L. Perrin and Victor A. Benassi. "The Connectedness to Nature Scale: A Measure of Emotional Connection to Nature?"' Journal of Environmental Psychology 29 (2009): 434 440 .

${ }^{31}$ Mayer and Frantz, Op. cit.

${ }^{32}$ Marybeth Pereira and Peter M. Forster. "The Relationship Between Connectedness to Nature, Environmental Values, and Pro-Environmental Behaviours." Reinvention: An International Journal of Undergraduate Research 8 (2015). <http://www .warwick.ac.uk/reinventionjournal/issues/volume8issue2/pereira $>$. 
behavior. Connection to nature is often operationalized in studies as having knowledge of or information about nature, having experiences in nature, demonstrating mindbody-spirit connections to nature that can be enlivened, or having deep or committed mind-body-spirit connectedness with nature that one lives fully. ${ }^{33}$

These arguments are important since there is a significant body of research that portrays blacks as being disconnected from nature. This line of research also suggests that because of their race and evolutionary past, blacks have unique outdoor recreational preferences. For instance, Kellert ${ }^{34}$ and Schroeder ${ }^{35}$ argue that blacks and urban dwellers are less likely to be oriented toward nature and are less knowledgeable about environmental issues than white suburbanites or white rural residents. Stamps and Stamps ${ }^{36}$ also espouse a race-based thesis by contending that regardless of the environment in which they live, blacks are more alike in their recreational pursuits and preferences than they are to whites.

However, there are a growing number of researchers who suggest that connections to nature and preferences for natural settings are more complex than the biologically based approaches imply. For instance, although Elmendorf et al. ${ }^{37}$ report that blacks in Philadelphia and Atlanta were less likely than whites in those cities to say that natural features such as streams, lakes, animals, and birds were important attributes of parks, the researchers also found that blacks were more likely to say they are willing to volunteer in neighborhood parks to facilitate development and upkeep than whites were. Peters et $a l^{38}$ report that concern and involvement with urban parks can facilitate attachment to such spaces.

${ }^{33}$ Matthew J. Zylstra, Andrew T. Knight, Karen J. Esler, and Lesley L.L. Le Grange. "Connectedness as a Core Conservation Concern: An Interdisciplinary Review of Theory and a Call for Practice." Springer Science Reviews 2 (2014): 119-143.

${ }^{34}$ Stephen R. Kellert. "Urban American Perceptions of Animals and the Natural Environment." Urban Ecology 8 (1984): 209-228.

${ }^{35}$ Schroeder (1990), Op. cit.

${ }^{36}$ Spurgeon M. Stamps and Miriam B. Stamps. "Race, Class and Leisure Activities of Urban Residents." Journal of Leisure Research 17 (1985): 40-56.

${ }^{37}$ William F. Elmendorf, Fern K. Willits, Vinod Sasidharan, and Geoffrey Godbey. "Urban Park and Forest Participation and Landscape Preference: A Comparison Between Blacks and Whites in Philadelphia and Atlanta, U.S." Journal of Arboriculture 31 (2005): 318-326.

${ }^{38}$ Karin Peters, Birgit Elands, and Arne Buijs. "Social Interactions in Urban Parks: Stimulating Social Cohesion?" Urban Forestry \& Urban Greening 9 (2010): 93-100.

${ }^{39}$ Deborah S. Carr and Daniel R. Williams. "Understanding the Role of Ethnicity in Outdoor Recreation Experiences." Journal of Leisure Research 25 (1993): 22-38.

${ }^{40}$ Kimberly J. Shinew, Myron F. Floyd, Francis A. McGuire, and Francis P. Noe. "Class Polarization and Leisure Activity Preferences of African Americans: Intra-Group Comparisons." Journal of Leisure Research 28 (1996): 219-232.

${ }^{41}$ Dorceta E. Taylor. "Urban Park Use: Race, Ancestry, and Gender." In: Paul H. Gobster, ed. Managing Urban and HighUse Recreation Settings. General Technical Report. NC-163. (U.S. Department of Agriculture, Forest Service, North Central Forest Experiment Station, 1993), 82-86.
Several researchers challenge the assumption that race is the pre-eminent determinant of connections to nature, landscape preferences, and leisure behavior. ${ }^{39,40,41} \mathrm{Shi}$ new et $a l .{ }^{42}$ argue that class matters whereas Virden and Walker ${ }^{43}$ make a cogent argument that gender is also an important factor in landscape preferences and leisure pursuits.

\section{Outdoor recreation and landscape preference}

Fear factor. Outdoor recreation and landscape preference studies are influenced by environmental psychology, so the theses and explanations overlap. As a consequence, some researchers studying outdoor leisure pursuits and affinity toward landscapes argue that blacks are disconnected from nature because they have an ingrained phobia about undisturbed natural settings that is driven by fear of wildlands. Fear leads to discomfort and avoidance of wildlands. Although some scholars challenge the assumptions that leisure behavior or landscape preferences are a function of genetics, evolution, adaptation, and are "hardwired," 44,45 the biophobia thesis persists in the literature (see Ulrich ${ }^{46}$ ).

Talbot and Kaplan ${ }^{47}$ embed their findings in this thesis. They argue that black Detroiters preferred manicured urban settings over undisturbed or minimally disturbed wooded settings. The researchers surmised that blacks preferred the open manicured settings over densely wooded landscapes because they feared the woods and sensed danger in it. Although Dwyer ${ }^{48}$ found that blacks were less likely to use remote areas of parks, he did not attribute the pattern of park usage to fear.

Other researchers have also examined the issue of fear in park use and interactions with nature. Gobster ${ }^{49}$ conducted a study of visitors in Chicago's Lincoln Park and found that blacks were less likely than whites to say they preferred the park's natural attributes over developed facilities, but Hispanics and Asians put a premiumto an equal extent or greater than whites-on naturalistic

\footnotetext{
${ }^{42}$ Shinew, et al., Op. cit.

${ }^{43}$ Randy J. Virden and Gordon J. Walker. "Ethnic/Racial and Gender Variations Among Meanings Given to, and Preferences for, the Natural Environment." Leisure Sciences 21 (1999): 219-239.

${ }^{44}$ Yannick Joye and Agnes Van den Berg. "Is Love for Green in Our Genes? A Critical Analysis of Evolutionary Assumptions in Restorative Environments Research." Urban Forestry \& Urban Greening 10 (2011): 261-268.

${ }^{45}$ Isabelle Blanchette. "Snakes, Spiders, Guns, and Syringes: How Specific are Evolutionary Constraints on the Detection of Threatening Stimuli?" Quarterly Journal of Experimental Psychology 5 (2006): 1484-1504.

${ }^{46}$ Ulrich (1993), Op. cit.

${ }^{47}$ Janet F. Talbot and Rachel Kaplan. (1984). "Needs and Fears: The Response to Trees and Nature in the Inner City." Journal of Arboriculture 10 (1984): 222-228.

${ }^{48}$ John F. Dwyer. "Outdoor Recreation Participation: An Update on Blacks, Whites, Hispanics, and Asians in Illinois." In: Paul H. Gobster, ed. Managing Urban and High-Use Recreation Settings. General Technical Report, NC-163. (U.S. Department of Agriculture, Forest Service, North Central Forest Experiment Station, 1993), 199-211.

${ }^{49}$ Gobster, Op. cit.
} 
features. Although research already discussed hypothesize or find that blacks fear being in natural settings, in the Lincoln Park study it was whites who were most concerned about safety. White park users were more than twice as likely as ethnic minority park users to fear for their safety. Brownlow $^{50}$ studied the Fairmount Park System in Philadelphia and found what he describes as a "legacy of fear towards the city's natural environment" that has significant and lingering impacts on African American women. However, it should be noted that the "natural environment" in the immediate vicinity of the study area consisted of acres of derelict, crime-ridden, weed-choked park lands that border the Cobbs Creek neighborhood-a low-income African American community.

Affinity for landscapes. Scholars argue that the degree of human influence is a key element in people's perceptions of and preferences for certain landscapes. ${ }^{51}$ Since the 1970s, several studies have compared the preferences of blacks and whites for urban, pastoral, or wild landscapes. For instance, investigators state that blacks prefer open and developed spaces, whereas whites had a preference for landscapes with dense forests and overgrown vegetation. ${ }^{52,53,54}$ Kielbaso $^{55}$ also reported that black Detroiters preferred open scenery and scenes with developed paths rather than dense woods and undeveloped paths.

Ho et al. ${ }^{56}$ found that blacks and Hispanics thought the presence of landscaping with manicured lawns and open vistas through the trees was very important to their park experience; Koreans, Chinese, whites, and Japanese were less enamored with these park features. Whites and Hispanics were more likely to rate the presence of wildlife in the park as important than the other ethnic groups. Hispanics and Chinese gave higher ratings to the presence of bodies of water than whites, Koreans, and Japanese. Blacks gave naturalistic park features the lowest ratings. But Hutch-

\footnotetext{
${ }^{50}$ Brownlow, Op. cit.

${ }^{51}$ Van den Berg and Koole, Op. sit.

${ }^{52}$ Ervin H. Zube, David G. Pitt, and T.W. Anderson. "Perception and Prediction of Scenic Resource Values of the Northeast." In: Ervin H. Zube, Robert O. Brush, Julius Gy Fabos, eds. Landscape Assessment: Values, Perceptions and Resources. (Hutchinson and Ross, 1975), 151-167.

${ }^{53}$ Ervin H. Zube and David G. Pitt. "Cross-Cultural Perceptions of Scenic and Heritage Landscapes." Landscape and Urban Planning 8 (1981): 69-87.

${ }^{54}$ Eddie Anderson. "Visual Resource Assessment: Local Perceptions of Familiar Natural Environments." (Doctoral diss., University of Michigan, 1978).

${ }^{55}$ J. James Kielbaso. "Preference of Detroit Residents for Urban Forests and Forestry Programs." Proceedings of the 1982 convention. Society of American Foresters. SAF Publication 83104. Library of Congress \# 83-60910. (Library of Congress, 1983).

${ }^{56}$ Ching-hua Ho, Vinod Sasidharan, William Elmendorf, Fern K. Willits, Alan Graefe, and Geoffrey Godbey. "Gender and Ethnic Variations in Urban Park Preferences, Visitation, and Perceived Benefits." Journal of Leisure Research 37 (2005): 281-306.

${ }^{57}$ Ray Hutchison. "Ethnicity and Urban Recreation: Whites, Blacks, and Hispanics in Chicago's Public Parks." Journal of Leisure Research 19 (1987): 205-222.
}

inson's ${ }^{57}$ findings point to the complexity of black leisure behavior. He studied 12 Chicago parks and found that the recreational pursuits of blacks and whites were more similar than the recreational pursuits of blacks and Hispanics or that of whites and Hispanics.

Other researchers such as Phillip ${ }^{58}$ state that blacks were much less likely than whites to think of wildland recreation areas as attractive tourist destinations. Johnson et al. ${ }^{59}$ also found that rural blacks were much less likely than rural whites to prefer recreational settings with wild landscapes. And, Gramann ${ }^{60}$ argues outright that "African Americans prefer more managed and developed outdoor recreation settings than whites" (p. 43).

Payne et al.'s ${ }^{61}$ study reinforces this trope with the finding that although blacks were more likely than whites to say that Cleveland needed more parks, whites were much more likely than blacks to say that park land should be used for conservation purposes or nature-based recreation. Battaglia et al. ${ }^{62}$ and Buckley ${ }^{63}$ also examine the theme of blacks' affinity for developed landscapes. They describe how residents of East Baltimore - a neighborhood comprising primarily African Americans-opposed tree planting efforts by arguing that they preferred clean and uncluttered concrete and that trees belong in the countryside, not the city.

Irwin et al. $^{64}$ studied camping among whites and Mexican Americans and found that both groups preferred minimally developed campgrounds; however, whites were more likely to prefer remote campsites than Mexican Americans. Bass et al. ${ }^{65}$ also found that Hispanics desired more developed amenities in natural areas in the Southwest than whites.

\footnotetext{
${ }^{58}$ Steven F. Philipp. "Racial Differences in the Perceived Attractiveness of Tourist Destinations, Interests and Cultural Resources." Journal of Leisure Research 25 (1993): 290-304.

${ }^{59}$ Cassandra Y. Johnson, J.M. Bowker, Donald B. English, and Dreamal Worthen. "Wildland Recreation in the Rural South: An Examination of Marginality and Ethnicity Theory." Journal of Leisure Research 30 (1998): 101-120.

${ }^{60}$ James H. Gramann. Ethnicity, Race, and Outdoor Recreation: A Review of Trends, Policy, and Research. Miscellaneous Paper (4-96-1). (U.S. Army Corps of Engineers, 1996).

${ }^{61}$ Laura L. Payne, Andrew J. Mowen, and Elizabeth OrsegaSmith. "An Examination of Park Preferences and Behaviors Among Urban Residents: The Role of Residential Location, Race, and Age." Leisure Sciences 24 (2002): 181-198.

${ }^{62}$ Michael Battaglia, Geoffrey L. Buckley, Michael Galvin, and Morgan Grove. "It's Not Easy Going Green: Obstacles to Tree Planting Programs in East Baltimore." Cities and the Environment 7 (2014). Available at: $<\mathrm{http}: / /$ digitalcommons.lmu.edu/ cate vol7/iss $2 / 6>$.

${ }^{63}$ Geoffrey L. Buckley. America's Conservation Impulse: A Century of Saving Trees in the Old Line State. (Center for American Places and Columbia College, 2010).

${ }^{64}$ Patricia N. Irwin, William C. Gartner, and Carolyn C. "Mexican American/Anglo Cultural Differences as Recreation Style Determinants." Leisure Sciences 12 (1990): 335-348.

${ }^{65}$ John M. Bass, Alan W. Ewert, and Deborah J. Chavez. "Influence of Ethnicity on Recreation and Natural Environment Use Patterns: Managing Recreation Sites for Ethnic and Racial Diversity." Environmental Management 17 (1993): 523-529.
} 
Taylor and Winter ${ }^{66}$ studied national forest visitors in southern California and found that Native Americans, African Americans, and whites were most likely to say that they visited the forest because of the scenery and wildlife. Asians tended to say they visited to socialize with family and friends, while Hispanics were most likely to visit so they can camp. However, Chavez ${ }^{67}$ reported that Hispanics preferred developed sites that facilitate social interactions to undeveloped recreational sites.

Stodolska and Livengood ${ }^{68}$ studied Muslim immigrants and found that they, too, preferred manicured spaces that facilitated family interactions over wilderness landscapes. However, Vasi ${ }^{69}$ discovered that Muslim women participated in a wide range of outdoor leisure activities, but women who had less than a college education were more likely to spend time indoors than more highly educated Muslim women did.

\section{Focus on students}

A limited number of studies have examined connectedness to nature and landscape preferences among American students. Peterson ${ }^{70}$ conducted a study of preference for scenery. He showed urban high school students photographs of landscapes and reported that black students preferred urban landscapes, whereas white students were more likely to be drawn to pastoral settings. Medina ${ }^{71}$ claims that black youths preferred urban scenes depicting commercial strips, whereas the environmental educators preferred scenes with tree-lined streets and natural areas with minimal or no disturbance. However, Hispanic and Asian high school students in Gearin and Kahle's ${ }^{72}$ study

\footnotetext{
${ }^{66}$ Dorceta E. Taylor and Patricia L. Winter. "Environmental Values, Ethics, and Depreciative Behavior in Wildland Settings." In: Deborah J. Chavez, ed. Proceedings of the Second Symposium on Social Aspects and Recreation Research. General Technical Report, PSWGTR-156. (U.S. Department of Agriculture, Forest Service, Pacific Southwest Research Station, 1995), 59-66.

${ }^{67}$ Deborah J. Chavez. Managing Outdoor Recreation in California: Visitor Contact Studies 1989-1998. General Technical Report, PSW-GTR-180. (USDA Forest Service, Pacific Southwest Research Station, 2001).

${ }^{68}$ Monika Stodolska and Jennifer S. Livengood. "The Influence of Religion on the Leisure Behavior of Immigrant Muslims in the United States." Journal of Leisure Research 38 (2006): $293-320$

${ }^{69}$ Jumana Vasi. "Environmentalism and Islam: A Study of Muslim Women in the United States." In: Dorceta E. Taylor, ed. Environment and Social Justice: An International Perspective (Research in Social Problems and Public Policy, Volume 18). (Emerald Group Publishing Limited, 2010), 451-484.

${ }^{70}$ George L. Peterson. Recreational Preferences of Urban Teenagers: The Influence of Cultural and Environmental Attributes. Children, Nature, and the Urban Environment. Proceedings of Symposium, U.S.D.A. Forest Service General Technical Report NE-30. (U.S. Department of Agriculture, North Forest Experiment Station, 1977).

${ }^{71}$ Augusto Q. Medina. “A Visual Assessment of Children's and Environmental Educators' Urban Residential Preference Patterns." (Ph.D. diss., University of Michigan, 1983).

${ }^{72}$ Elizabeth Gearin and Chris Kahle. "Teen and Adult Perceptions of Urban Green Space in Los Angeles." Children, Youth and Environments 16 (2006): 25-48.
}

told the researchers that they hated the dirtiness of nearby parks and "all the paved cement" in them (p. 35).

Bixler et $a{ }^{73}{ }^{73}$ explored urban students' fear of and discomfort in wildland areas in their research by asking 48 interpreters to report how students responded to nature on field trips they led. The interpreters said that students were fearful of animals, trees, and people while in the wilds. In 1997, Bixler and Floyd ${ }^{74}$ studied 450 suburban and rural eight graders in Texas and found that many of the students were fearful of and disgusted by wildlands. They found that strong fear and disgust resulted in aversion to wild landscapes, preference for manicured park spaces and urban environments, and a desire to work and recreate indoors. Floyd et al. ${ }^{75}$ studied 1200 black and white middle and high school students and reported that white students tended to rate wildland activities more highly than blacks. They found that fear was a factor in the students' ratings, that is, fear of nature and preference for urban environments were positively related to a desire to participate in social activities that did not occur in wildlands.

Despite being a large and relatively influential segment of the adult population, few studies have focused on college students. Virden and Walker ${ }^{76}$ studied 323 students attending a public university in the western United States and found that whites and Hispanics preferred more remote, less developed settings than blacks. In the end, they concluded that the white participants in their study "considered a forest to be safer than Black and Hispanic respondents, who perceived it as more threatening" (p. 233).

Manning ${ }^{77}$ studied how connected students at Southern Utah University were to nature and found that male students scored higher on the connectedness-to-nature scale. He also found urban students had higher scores on the scale than suburban and rural students. Lankenau ${ }^{78}$ also studied university students and found that an introductory ecology course enhanced students' connectedness to nature. But Nisbet et al. ${ }^{79}$ who studied college students enrolled in semester-long environmental courses, did not witness any changes in the level of students' connectedness to nature that resulted from taking the course.

\footnotetext{
${ }^{73}$ Bixler, et al., Op. cit.

${ }^{74}$ Bixler and Floyd, Op. cit.

${ }^{75}$ Myron F. Floyd, Corliss W. Outley, Robert D. Bixler, and William E. Hammitt. "Effect of Race, Environmental Preference and Negative Affect on Recreation Preferences." In: Abstracts from the 1995 National Recreation and Parks Association on Leisure Research. (National Recreation and Park Association, 1995), 88.

${ }^{76}$ Virden and Walker, Op. cit.

${ }^{77}$ Jacob W. Manning. "Connectedness to Nature Among University Freshman and New Transfer Students." (Ph.D. diss., Southern Utah University, 2012).

${ }^{78}$ Greg R. Lakenau. "Fostering Connectedness to Nature in Higher Education." Environmental Education Research 24 (2018): 230-244.

${ }^{79}$ Elizabeth Nisbet, John M. Zelenski, and Steven A. Murphy. "Happiness is in Our Nature: Exploring Nature Relatedness as a Contributor to Subjective Wellbeing." Journal of Happiness Studies 12 (2011): 303-322.
} 


\section{SIGNIFICANCE OF THE TOPIC AND CONCEPTUAL FRAMEWORK}

\section{Critique of traditional approaches}

This topic is noteworthy because, as the aforementioned discussion shows, segments of the connectedness-to-nature and the landscape preference literature portray the relationship that blacks and other racial and ethnic minorities have with nature as antagonistic and negative. Most noticeably, the reliance on the biophobia thesis leads investigators to oversimplify the relationship that blacks have with nature and their perceptions of the wilds. Taylor ${ }^{80}$ uses an EJ approach to counter this narrative by documenting the long history of intimate knowledge and deep understanding that blacks and other people of color have for the forests throughout American history. For instance, slaves used the woods for healing, spiritual uplift, sustenance, and as a space in which to oppose oppression and violence. During the nineteenth and early twentieth centuries, the white middle class traveled to remote locations, explored the wilderness, built country estates and cottages in the woods, and participated in outdoor leisure pursuits. The black middle class were driven by similar Romantic impulses but when they tried to emulate their white counterparts, blacks were locked out of exclusive resorts, national parks, and other natural wonders. In response to segregated recreational spaces, blacks created their own resorts at places such as Hot Springs, Arkansas, and wilderness retreats such as Idlewild in Michigan. Blacks participated in the outdoor movement by allowing their children to become scouts and join similar groups such as the Campfire Clubs. But to gain widespread access to wildlands and parks, blacks had to engage in equity and antidiscrimination battles to get into many of the nation's naturalistic and wild spaces. So, emboldened by the civil rights activism sweeping the nation, blacks intensified their campaigns to desegregate national parks as well as city parks during the 1960s and 1970s. Although they were not labeled as such, the park desegregation campaigns were EJ crusades that blacks, seeking greater connectedness to nature, launched successfully.

Still, some believe that the connections blacks once had with the forests have turned into disassociation. ${ }^{81,82}$ Johnson $^{83}$ claims that blacks' aversion to wild landscapes can arise from the collective memory of slavery, lynching, and other acts of violence visited on African Americans in the woods. Johnson studied 147 whites and 116 African Americans in Gadsen County, Florida, and found race to be a strong predictor of attachment to wildlands. The study revealed that blacks were less likely than whites to have strong attachments to wildlands.

Despite claims that blacks are disassociated from nature and have an aversion to it, there is a proliferation of

\footnotetext{
${ }^{80}$ Taylor (2016), Op. cit.

${ }^{81}$ Cynthia Y. Johnson. "A Consideration of Collective Memory in African American Attachment to Wildland Recreation Places." Human Ecology Review 5 (1998): 5-15.

${ }^{82}$ Lewis and Hendricks, Op. cit.

${ }^{83}$ Johnson, Op. cit.
}

outdoor groups such as Outdoor Afro (that has branches in $>30$ states) ${ }^{84}$ and Journey Outdoors. Founded in 1996, Journey Outdoors has chapters across the United States that cater to black hikers, backpackers, mountaineers, cyclists, mountain bikers, kayakers, canoers and rowers, white-water rafters, scuba divers, skiers, ice climbers, campers, sailors, rock climbers, spelunkers, runners, horseback riders, and birders. ${ }^{85}$ Other black outdoor groups include the African American Hunting Association. ${ }^{86}$ Thus, the disassociation-aversion thesis does not explain the existence and success of these groups or events such as the MLK Ski Weekend, the Blackout Ski Weekend, and other black skiing events that occur across the country. Furthermore, the thesis does not help us to understand the behavior of the all-black team of mountain climbers who ascended the summit of Mount McKinley, the highest peak in North America. ${ }^{87}$ These responses to nature and the outdoors by blacks suggest that researchers might be overestimating the extent to which they think blacks are disassociated from nature.

A recent study by Freeman and Taylor ${ }^{88}$ also demonstrates that blacks are not universally repulsed by natural landscapes or disassociated from them. The researchers studied 119 black recreationers who traveled to the Smith Family Park, a black-owned farm that-in an effort to remain solvent-converted part of its holdings into camping and outdoor recreation space. Respondents were most likely to say they viewed nature, went fishing, watched or interacted with wildlife, camped, went birdwatching, and hiked while visiting the park. The Smith Park case demonstrates how equity, justice, economic self-help, and racial uplift are intertwined with connections to nature.

Yet, environmental psychologists and landscape preference scholars have been slow to recognize and examine how social and structural barriers can influence perceptions of nature and connectedness to it. Investigators who are attuned to this interrogate these things in their research and include these factors in their explanations. For instance, racial discrimination influences how people experience landscapes. Thus, ethnic minority park users report that they experience racism, discrimination, and cultural exclusion in parks and recreational areas, and

\footnotetext{
${ }^{84}$ Rue Mapp. "Outdoor Afro: Where Black People and Nature Meet-Our Impact." 2017. <http://outdoorafro.com/impact>.

${ }^{85}$ Hera-Ka Anu. "Welcome to Journey Outdoors." 2016. $<$ http://www.journeyoutdoors.org/index.html $>$.

${ }^{86}$ Donny R. Adair. "African American Hunting Association LLC Benefit Statement." April 1, 2013. <https://outdoorshow wordpress.com>.

${ }^{87}$ James Mills, J. "All African-American Team Takes on Denali-Why it Matters." National Geographic. May 9, 2013. $<$ http://adventureblog.nationalgeographic.com/2013/05/09/firstall-african-american-team-takes-on-denali-in-june-why-it-matters/> .

${ }^{88}$ Stephanie Freeman and Dorceta E. Taylor. "Heritage Tourism: A Mechanism to Facilitate the Preservation of Black Family Farms." In: Dorceta E. Taylor, ed. Environment and Social Justice: An International Perspective (Research in Social Problems and Public Policy, Volume 18. (Emerald Group Publishing Limited, 2010), 261-285.
} 
such experiences lead them to avoid visiting these spaces. ${ }^{89}$ Other EJ scholars also discuss similar findings. ${ }^{90}$ Nonetheless, scholars continue to use the biophilia thesis without accounting for the ways in which factors such as racism, discrimination, and exclusion influence affinity toward nature.

Scholars concerned with landscape preferences, outdoor recreation, and connectedness to nature also do not fully recognize that not all encounters with the natural environment result in improved well-being. Even casual encounters with nature can lead to emergencies. For instance, Bartlett ${ }^{91}$ found that black and Hispanic youths in Flint, Michigan, avoid traversing the city's numerous overgrown, weed-strewn landscapes because such spaces can trigger allergies and severe asthma attacks. Farquhar et al. ${ }^{92}$ had similar findings in Detroit. Katz and Carey ${ }^{93}$ found that residents living in low-income ethnic minority neighborhoods in Detroit are disproportionately affected by allergenic ragweed pollen. These types of interactions with nature - those that result in illnesses-are not usually factored into the interpretation of how blacks and other minorities interact with nature.

\section{An environmental justice framework}

The tendency to frame the relationships that blacks and other minorities have with nature as deficient is consistent with broader narrative about people of color and the environment. Racial and ethnic minorities are often viewed as lacking interest in and concern for the environment, lacking in knowledge about it, and having negative attitudes toward the environment. Whites, in contrast, are generally characterized as interested in, concerned for, and knowledgeable about nature and the environment (see Taylor ${ }^{94,95}$ for extensive reviews of this literature). EJ practitioners have challenged this characterization since the 1980s. Moreover, the formation of hundreds of EJ organizations nationwide in the past four

\footnotetext{
${ }^{89}$ Nina S. Roberts and Tendai Chitewere. "Speaking of Justice: Exploring Ethnic Minority Perspectives of the Golden Gate National Recreation Area." Environmental Practice 13 (2011): 354-369.

${ }^{90}$ Carolyn Finney. Black Faces, White Spaces: Reimagining the Relationship of African Americans to the Great Outdoors. (University of North Carolina Press, 2014).

${ }^{91}$ M'Lis Bartlett. "Participatory Landscape Design with Urban Minority Teens: Building Collective Efficacy for Landscape Stewardship." (Ph.D. diss., University of Michigan, 2015).

${ }^{92}$ Stephanie A. Farquhar, Edith A. Parker, Amy J. Shulz, and Barbara A. Israel. "In Their Words: How Detroit Residents Perceive the Effects of Their Physical Environment." Local Environment 10 (2005): 259-274.

${ }^{93}$ Daniel S. Katz and Tiffany S. Carey. "Heterogeneity in Ragweed Pollen Exposure is Determined by Plant Composition at Small Spatial Scale." Science of the Total Environment 435440 (2014): 485-486.

${ }^{94}$ Dorceta E. Taylor. The State of Diversity in Environmental Organizations: Mainstream NGOs, Foundations, Government Agencies. Report prepared for Green 2.0 and the Raben Group. (University of Michigan, 2014).

${ }^{95}$ Dorceta E. Taylor. "Gender and Racial Diversity in Conservation Organizations: Uneven Accomplishments and Cause for Concern." Environmental Justice 8 (2015): 165-180.
}

decades attests to the interest minorities have in the environment. Although the portrayal of minorities has become more nuanced, EJ activism and counter-framing have not fully quieted arguments about ethnic minority environmental disinterest and inadequacies. ${ }^{96,97}$

This article employs an EJ framework to question the ways in which racial and ethnic minorities are portrayed vis-à-vis nature and the environment. It challenges the arguments that blacks and other ethnic minorities are disconnected from nature, are averse to it, and prefer urbanized and developed landscapes to natural landscapes. It avoids the racial determinism that underpins the proposition that these responses and preferences are fixed and are biologically based. The article does this by examining and highlighting how study participants adjust their responses to nature as situations change. As a result, three explanatory concepts emerged from the thematic analysis of responses provided by participants. They are (1) situational fear, (2) object-specific dislike, and (3) simultaneous contradictions.

The author argues that when fear is expressed during interactions with nature, it is not always the generalized fear described in the studies previously cited. Fear can be situational, for example, it can be evoked through a specific situation, condition, or experience. For instance, someone caught in a blizzard or witnessing a lightning strike in a forest may feel fearful at the time these things are occurring, but that fear can be transitory. Situational fear may be momentary or more long term, but it does not preclude a person from experiencing nature without being fearful. That is, situational fear may not rise to a level of permanent and generalized fear of nature or wild landscapes. Object-specific dislike occurs when individuals identify a landscape feature that bothers them. For instance, the presence of venomous creatures, poisonous flora, or a paved trail influences how people respond to nature and landscapes. Here, the response is to a specific object or feature in the landscape, the absence of which evokes a positive or neutral emotion. This article also argues that humans experience a myriad of emotions simultaneously while experiencing nature. That is why when they examine landscapes, they can express contradictory views, feelings, and emotions concomitantly. Research already discussed has not elucidated this phenomenon, consequently, we do not know how prevalent this occurrence is.

\section{THE STUDY}

\section{Sampling methodology}

This study used a purposive sampling technique to identify and survey students who participated in science, technology, engineering, and mathematics programming at a large public midwestern university, a medium-sized private mid-Atlantic university, and a small private historically black university in the deep south. Between May 4, 2016, and June 21, 2016, surveys were sent to 391

\footnotetext{
${ }^{96}$ Ibid.

${ }^{97}$ Taylor (2014), Op. cit.
} 
students before they started summer enrichment programs. The surveys, administered through a Qualtrics platform, allowed for anonymity. Images could be embedded in the survey, and the platform also prevented an individual from responding to the survey more than once. The survey was designed with open responses to encourage reflections and elicit explanations as well as closed-ended Likert scale questions. Usable surveys were received from 161 students. The effective response rate was $41.2 \%$.

\section{Landscape preference methodology}

A series of eight color pictures of different types of landscapes were presented to each respondent one at a time. These images were embedded in the Qualtrics survey as .jpg files that were displayed on the screen as photographs. The pictures, shown one at a time, were categorized as (1) two forest scenes-one natural and one with minimal disturbance, (2) two aquatic scenes-one natural and one with built structures, (3) two urban parks featuring the built environment-one had a closed canopy of trees and the other featured open vistas, and (4) wildlife scenes-one predator and one invasive species. Upon viewing each photograph, respondents were asked to indicate how they felt about the picture. They rated each landscape on a Likert scale ranging from 1 to 5; $1=$ dislike a lot, $2=$ dislike a little, $3=$ neither like nor dislike, $4=$ like a little, and $5=$ like a lot. After rating the picture, respondents were asked to explain why they rated it the way they did. The explanations took the form of open-ended responses. After rating and explaining the reasoning for their rating, respondents could move on to the next photograph and repeat the process till all eight pictures were viewed and rated.

\section{Data analysis}

Data were downloaded from the Qualtrics surveys and analyzed in SPSS 24. Because the sample size was small, information collected from Likert scales was collapsed into three or four categories to conduct analyses. This ensured that cell counts were high enough to withstand descriptive procedures. Crosstabulations were used to examine the data. Where possible, the means of variables were compared to facilitate further analysis. Analysis of variance (ANOVA) was conducted and reported for the means comparisons. ANOVAs allowed the researcher to identify significance levels for the interactions studied.

\section{Sample characteristics}

Four students refrained from identifying their racial background, so 157 responses were analyzed in this article. This sample consists of $46(29.3 \%)$ white students, 43 (27.4\%) black students, and $68(43.3 \%)$ other ethnic minority students. The category, other ethnic minority students, consists of students who are of Native American, Pacific Islander, Hispanic or Latino/a, Asian, Arab/Middle Eastern, and biracial/multiracial heritage. The sample size for each of these groups was too small to analyze separately.

The sample contains both undergraduates and graduate students. A total of 116 or $73.9 \%$ of the sample are un- dergraduates. The remaining 41 or $26.1 \%$ are graduate students. Respondents range in age from 18 to 46 years of age. Study participants specialize in a variety of subject areas. All but one respondent listed their major. Fortyfour percent are environmental science/environmental studies/environmental policy majors, $24 \%$ major in biology/ecology, $6 \%$ in engineering, and the remaining $26 \%$ in agriculture, general studies, communication, computer science, history, urban planning, sociology, American studies, political science, social work, architecture, biotechnology, nursing, dentistry, geography, global studies, landscape architecture, English, math, forestry, public health, psychology, East Asian studies, environmental education, higher education administration, and operations technology management.

\section{RESULTS}

\section{Perceptions of nature}

Before being shown any pictures, respondents were asked to say what comes to their minds when they think of nature. This was an open-ended question. The major themes articulated in the responses were identified, coded, and analyzed. Themes identified by more than one respondent are summarized in Table 1. Quotes from respondents will also be used as part of the presentation of the results. At times, the gender of the respondent and quotes from specific racial or ethnic respondents categorized as "other minorities" will be identified because naming the gender and race/ethnicity of the respondent helps the reader to understand the similarities and differences in the way study participants perceive and respond to questions about nature and landscape preferences.

As Table 1 shows, study participants cogitate about a wide range of things when they think about nature. There is considerable overlap in what respondents ponder. Respondents are most likely to say that when they think of nature they think of trees, forests, and plants. Seventytwo respondents- $45.9 \%$ of the sample-consider this. Although about $42 \%$ of blacks ponder trees, forests, and plants when they think of nature, roughly $46 \%$ of whites and $49 \%$ of other minorities do likewise. The variances in percentage between the groups are insignificant.

There is less consensus when it comes to thinking of animals. About $29 \%$ of the respondents think of animals when they think of nature but there are noticeable differences between the groups. Roughly $40 \%$ of other minorities think of animals, so do $28.3 \%$ of whites. However, blacks are significantly less likely than other racial and ethnic groups to think of animals when they think about nature-only $14 \%$ consider animals when they think of nature.

Although a fourth of other minorities think of water/ oceans/lakes/rivers when they contemplate nature, only $13.9 \%$ of blacks and $10.9 \%$ of whites think of these things when thinking of nature. Virtually identical percentages of whites and other minorities think of the outdoors when they consider nature $(19.6 \%$ and $19.1 \%$, respectively); however, a much lower percentage of blacks $(9.3 \%)$ think of this factor when they cogitate 
Table 1. What Comes to Mind When Respondents Think of Nature

\begin{tabular}{|c|c|c|c|c|c|c|c|c|}
\hline \multirow[b]{2}{*}{ Thoughts of nature } & \multirow{2}{*}{$\begin{array}{c}\text { Sample } \\
\text { total } \\
(\mathrm{n}=157)\end{array}$} & \multirow{2}{*}{$\begin{array}{c}\text { Sample } \\
\%\end{array}$} & \multicolumn{2}{|c|}{ White $(\mathrm{n}=46)$} & \multicolumn{2}{|c|}{ Black $(\mathrm{n}=43)$} & \multicolumn{2}{|c|}{$\begin{array}{l}\text { Other ethnic } \\
\text { minorities }(\mathrm{n}=68)\end{array}$} \\
\hline & & & $\mathrm{n}$ & $\%$ & $\mathrm{n}$ & $\%$ & $\mathrm{n}$ & $\%$ \\
\hline Trees, forests, plants & 72 & 45.9 & 21 & 45.7 & 18 & 41.9 & 33 & 48.5 \\
\hline Animals & 46 & 29.3 & 13 & 28.3 & 6 & 14.0 & 27 & 39.7 \\
\hline Water, oceans, lakes, rivers & 28 & 17.8 & 5 & 10.9 & 6 & 14.0 & 17 & 25.0 \\
\hline The outdoors & 26 & 16.6 & 9 & 19.6 & 4 & 9.3 & 13 & 19.1 \\
\hline Green spaces & 24 & 15.3 & 6 & 13.0 & 9 & 20.9 & 9 & 13.2 \\
\hline Undisturbed landscapes & 24 & 15.3 & 6 & 13.0 & 5 & 11.6 & 13 & 19.1 \\
\hline Needs protection, preservation & 18 & 11.5 & 5 & 10.9 & 4 & 9.3 & 9 & 13.2 \\
\hline Peaceful, tranquil & 16 & 10.2 & 3 & 6.5 & 4 & 9.3 & 9 & 13.2 \\
\hline Environments we live in & 15 & 9.6 & 4 & 8.7 & 4 & 9.3 & 7 & 10.3 \\
\hline Recreation & 14 & 8.9 & 6 & 13.0 & 3 & 7.0 & 5 & 7.4 \\
\hline Human interactions & 12 & 7.6 & 5 & 10.9 & 5 & 11.6 & 2 & 2.9 \\
\hline Ecosystems, biomes & 12 & 7.6 & 3 & 6.5 & 2 & 4.7 & $\overline{7}$ & 10.3 \\
\hline Species interactions & 11 & 7.0 & 4 & 8.7 & 3 & 7.0 & 4 & 5.9 \\
\hline Wild, wilderness, untamed & 11 & 7.0 & 2 & 4.3 & 2 & 4.7 & 7 & 10.3 \\
\hline Scenic, beautiful & 10 & 6.4 & 2 & 4.3 & 4 & 9.3 & 4 & 5.9 \\
\hline Mountains & 9 & 5.7 & 3 & 6.5 & 1 & 2.3 & 1 & 1.5 \\
\hline Parks & 9 & 5.7 & 2 & 4.3 & 3 & 7.0 & 4 & 5.9 \\
\hline Natural world & 9 & 5.7 & 3 & 6.5 & 5 & 11.6 & 1 & 1.5 \\
\hline Fresh air & 8 & 5.1 & 2 & 4.3 & 3 & 7.0 & 3 & 4.4 \\
\hline Natural resources & 7 & 4.5 & & & & & 7 & 10.3 \\
\hline It is home & 6 & 3.8 & 1 & 2.2 & 1 & 2.3 & 4 & 5.9 \\
\hline Grasslands & 5 & 3.2 & & & 1 & 2.3 & 4 & 5.9 \\
\hline Beaches & 5 & 3.2 & 1 & 2.2 & 2 & 4.7 & 2 & 2.9 \\
\hline Intrinsic beauty & 4 & 2.5 & 2 & 4.3 & & & 2 & 2.9 \\
\hline Sun, sunshine & 4 & 2.5 & 1 & 2.2 & & & 3 & 4.4 \\
\hline Sustains life & 4 & 2.5 & 1 & 2.2 & & & 3 & 4.4 \\
\hline Connecting to it & 4 & 2.5 & 1 & 2.2 & & & 3 & 4.4 \\
\hline Soils & 4 & 2.5 & 1 & 2.2 & 2 & 4.7 & 1 & 1.5 \\
\hline Complex interactions & 4 & 2.5 & 1 & 2.2 & 2 & 4.7 & 1 & 1.5 \\
\hline Man-made hazards & 4 & 2.5 & & & 2 & 4.7 & 2 & 2.9 \\
\hline Learning from nature & 4 & 2.5 & & & 2 & 4.7 & 2 & 2.9 \\
\hline My environment & 3 & 1.9 & 1 & 2.2 & 1 & 2.3 & 1 & 1.5 \\
\hline Nature is everything & 3 & 1.9 & 2 & 4.3 & 1 & 2.3 & & \\
\hline Love & 3 & 1.9 & 1 & 2.2 & 1 & 2.3 & 1 & 1.5 \\
\hline Climate change & 3 & 1.9 & 1 & 2.2 & & & 2 & 2.9 \\
\hline Deserts & 3 & 1.9 & & & & & 3 & 4.4 \\
\hline Happiness & 3 & 1.9 & & & 1 & 2.3 & 2 & 2.9 \\
\hline Freedom & 3 & 1.9 & & & 1 & 2.3 & 2 & 2.9 \\
\hline Tundra & 2 & 1.3 & 1 & 2.2 & & & 1 & 1.5 \\
\hline God, religion & 2 & 1.3 & 1 & 2.2 & & & 1 & 1.5 \\
\hline Flowers & 2 & 1.3 & 1 & 2.2 & 1 & 2.3 & & \\
\hline Biodiversity & 2 & 1.3 & 1 & 2.2 & & & 1 & 1.5 \\
\hline It is alive & 2 & 1.3 & & & & & 2 & 2.9 \\
\hline Rocks & 2 & 1.3 & & & & & $\overline{2}$ & 2.9 \\
\hline Therapeutic, healing & 2 & 1.3 & & & 1 & 2.3 & 1 & 1.5 \\
\hline Humans connected to nature & 2 & 1.3 & & & 1 & 2.3 & 1 & 1.5 \\
\hline Safe space, refuge & 2 & 1.3 & & & 1 & 2.3 & 1 & 1.5 \\
\hline Provides food & 2 & 1.3 & & & & & 1 & 1.5 \\
\hline The universe & 2 & 1.3 & & & 1 & 2.3 & 1 & 1.5 \\
\hline
\end{tabular}

nature. The reverse is true for thinking of green spaces: a higher percentage of blacks $(20.9 \%)$ think about green spaces when they think of nature than other minorities $(13.2 \%)$ or whites $(13.0 \%)$.

Whites are almost twice as likely to think of nature as a recreational space than blacks or other minorities. Whites and blacks are also much more likely to think of human interactions when they think of nature than other minorities were inclined to do. Although $4.4 \%$ of whites and $5.9 \%$ of other minorities think about scenic beauty when they consider nature, $9.3 \%$ of blacks do.

Although researchers report that blacks fear nature, none of the respondents in this study state that fear comes to mind when they think of nature. Although respondents think of the "environments we live in" or "my environment" when thinking about nature, there were only 
four references to man-made hazards and one to urban nature.

Like other students in the study, black respondents are enthusiastic about nature and express connectivity to it. Hence black students say, "When I first hear nature, the first thing that comes to mind is a clean and pristine forest. I think of everything in its natural habitat," and "Nature translates immediately to me in green spaces and forests." However, blacks expressed much more complicated views of nature too. The complexity of their thoughts about nature is reflected in statements such as

Images of the physical environment come to mind (trees, soil, sky, etc.) [when I think of nature]. Then I think of the ideologies that say that humans are separate and superior to nature, but I think we might be in a much better place without these ideologies.

Another states,

When I hear the word nature I think of wonderful gifts the earth gives us such as beaches, woods and various parts of the earth that isn't necessarily surrounded by various buildings.

For yet another, thinking of nature brought forth the following vision:

1st thought: trees and physical environment. I see varying green forested areas that I have visited or spent an extended time in. 2nd: "human nature," I thought purely of the word, nothing more. 3rd: destruction of environment, destruction of nature. 4th: ambient environment, clean [and] fresh air and happy memories being in nature.

Black respondents also associate nature with tranquility, freedom, refuge, culture, and survival. One respondent writes,

For me, nature [is] a place of tranquility. I've also had many healing experiences in the outdoors. Nature is also a place where I do exercise and hangout with family and friends. Also, I often think about my African American and Native American ancestors when I reflect on the landscapes of my home. Forests were places of refuge and where they were able to survive. I think about them often when I'm in the outdoors. My family also loves to fish. I think about my grandfather and cousins who took me fishing with them when I was a child.

The respondent continues,

Currently I'm working on decolonizing my relationship with nature and exploring the various ways to engage with nature through work, spirituality, learning etc. I think this deconstructing the separation between humans and nature will be crucial as we navigate this time-space we're in.

Another respondent echoed similar sentiments in her response,

When I hear the word nature, I think of freedom. Freedom to explore what the world has to offer me. Being in an allnatural environment is very relaxing and welcoming, so nature plays a huge role in my life.

Other black students thought of nature as ecosystems. They said, "Nature is one of the most essential aspects to our ecosystem...it is our job to try to conserve it," and
I think of a balanced ecosystem that has not been significantly degraded by human activity. The image of Yosemite Valley minus the thousands of tourists comes to mind.

A similar range and complexity of thoughts about nature was expressed by other ethnic minority students too. For instance, one Asian respondent says, when I think of nature I think of

Lush lands ranging from forests, to savannas, to the Arctic tundra-filled with animals and organisms. I also see streams, and imagine birds chirping. I don't see the presence of human beings though.

Another Asian respondent writes, "When I think of nature I immediately think about the tropical rainforests." Upon reflection, a Hispanic student notes, "I think of the natural world...I think of parks, national parks, rainforests, deserts, and many more different types of biomes." Another Hispanic student says,

When I hear the word nature, I think of the great outdoors. I think of a place far away from the city where ecosystems are undisturbed and left to function as they were meant to.

A third Hispanic student writes,

Nature encompasses everything and everyone. Whether you choose to look at it through the ecological lens or the psychological one. Nature gives us the ability to sustain our very existence and it is important that we do everything in our power to protect it... When we can provide for it, nature can provide for us.

Native American students also think of nature in terms of the outdoors, tranquility, and the need for protection. They say when they think of nature, "Green, outdoors, away from technology and other distractions, peace," "The wilderness of the great outdoors and how they represent a certain ecosystem," and "The world around us that needs to be protected and nurtured," come to mind.

White students educe similar themes. One writes,

Nature describes ecosystems and the organisms that inhabit those ecosystems in their natural state with either limited or no human interaction.

Another says,

I think of the open outdoors, and for me particularly I really think about the ocean since it's my favorite part of nature.

A third white student who finds the outdoors a salient part of her thoughts about nature says, "When I hear nature I think of the outdoor[s]. I think of plants and trees and the animals around us." A white male student who thinks of human-environment interactions states that the following vision surfaces when he thinks of nature.

The environments we live in, the things that surround; this includes the people we surround ourselves with and the relationships we develop.

Lastly, another notes,

I think of peace and tranquility. It should be preserved to maintain these opportunities that nature has brought to us. 


\section{Connectedness to nature}

So, how connected to nature are these respondents? Study participants were asked to say what their sense of connectedness to nature is. Participants indicated their response on a 5-point Likert scale: $1=$ very disconnected, $2=$ somewhat disconnected, $3=$ neither connected nor disconnected, $4=$ somewhat connected, and $5=$ very connected.

None of the respondents say they are very disconnected or somewhat disconnected from nature. Moreover, $<8 \%$ of the respondents felt neutral about nature-neither connected nor disconnected (Table 2). Overall, $54.8 \%$ of the respondents said they feel somewhat connected to nature and another $37.6 \%$ said they feel very connected to nature. Blacks stood out in the extent to which they say they feel very connected to nature. They are less likely than other respondents to say they feel very connected to nature. That is, $20.1 \%$ of blacks, $42.6 \%$ of other minorities, and $45.7 \%$ of whites report that they feel very connected to nature. Despite the low percentage of blacks saying they feel very connected to nature, it should be noted that the majority of blacks $(69.8 \%)$ say they feel somewhat connected to nature.

\section{Curiosity about nature}

Respondents were also asked to say how curious they are about nature. They ranked their curiosity on a 5-point Likert scale: $1=$ very incurious, $2=$ somewhat incurious, $3=$ neither curious nor incurious, $4=$ somewhat curious, and $5=$ very curious. Respondents are much more likely to state that they are very curious about nature than they are to indicate that they are very connected to nature. This is the case for the three groups studied. Overall, $71.3 \%$ of the respondents say they are very curious about nature and another $26.1 \%$ are somewhat curious about it.

Respondents categorized as other minorities were most likely to say they are very curious about nature- $-82.4 \%$ of them were very curious. In comparison, $73.9 \%$ of whites and $51.2 \%$ of blacks feel very curious about nature. Although the only person who said he or she is incurious about nature is black, more than half of the black respondents are very curious about nature, and $44.2 \%$ are somewhat curious about nature.

\section{Landscape preferences}

After revealing how connected to nature they feel and their level of curiosity about nature, respondents were shown eight landscape images and asked to say whether they like or dislike the pictures. In an additional step, study participants were also asked to explain how they feel about the scenery depicted in each photograph. Here, many took the opportunity to be explicit about why they like or dislike what is depicted in each photograph.

Table 3 shows the descriptions of the landscapes, the order in which the photographs were shown, and the category into which the landscapes are grouped. Respondents had a range of responses to the photographs. Roughly $88 \%$ of the respondents reported that they like the picture of a forested chain of islands and inlets a lot. However, respondents are far less captivated by a picture depicting an urban park with expanses of manicured lawn visible through the trees; only $26.1 \%$ of the respondents say they like this picture a lot.

Forest scenes. The first picture shown features a dense coniferous forest with an opening provided by two fallen, overgrown logs in the center of the scene. Most of the respondents $(73.7 \%)$ indicate that they like this photograph a lot. Although $>78 \%$ of whites and other minorities like this picture a lot, $59.5 \%$ of blacks do (Table 3). The ANOVA of the means show that the differences are significant $(F=3.619, p=0.029)$. Although the sample mean is 4.58 , the mean is 4.29 for blacks, 4.67 for whites, and an almost identical mean of 4.69 for other minorities (see Table 4 for the ANOVA

Table 2. Racial and Ethnic Differences in the Sense of Connectedness to AND CURIOSITY About Nature

\begin{tabular}{lccc}
\hline & \multicolumn{4}{c}{$\%$} \\
\cline { 2 - 4 } Race or ethnicity & \multicolumn{4}{c}{ Connectedness to nature } \\
\cline { 2 - 4 } & Neither connected nor disconnected & Somewhat connected & Very connected \\
Total sample & 7.6 & 54.8 & 37.6 \\
White or Caucasian & 9.3 & 50.0 & 45.7 \\
Black & 8.3 & 69.8 & 20.9 \\
Other minorities & 8.8 & 48.5 & 42.6 \\
\hline
\end{tabular}

Curiosity about nature

\begin{tabular}{lccc} 
Race or ethnicity & Neither curious nor not curious & Curious & Very curious \\
\hline Total sample & 1.9 & 26.1 & 71.3 \\
White or Caucasian & 2.2 & 23.9 & 73.9 \\
Black & 2.3 & 44.2 & 51.2 \\
Other minorities & 1.5 & 16.2 & 82.4 \\
\hline
\end{tabular}


Table 3. Racial Differences in the Percentage of Respondents Saying They LiKe Each Landscape a LitTle or a Lot

\begin{tabular}{|c|c|c|c|c|c|c|c|c|}
\hline \multirow[b]{3}{*}{ Landscape descriptions } & \multirow[b]{3}{*}{$\begin{array}{c}\text { Order } \\
\text { of photos }\end{array}$} & \multirow[b]{3}{*}{$\begin{array}{c}\text { Photo } \\
\text { category }\end{array}$} & \multicolumn{6}{|c|}{$\%$} \\
\hline & & & \multicolumn{2}{|c|}{ White } & \multicolumn{2}{|c|}{ Black } & \multicolumn{2}{|c|}{$\begin{array}{l}\text { Other ethnic } \\
\text { minorities }\end{array}$} \\
\hline & & & $\begin{array}{l}\text { Like } \\
\text { a little }\end{array}$ & $\begin{array}{l}\text { Like } \\
\text { a lot }\end{array}$ & $\begin{array}{l}\text { Like } \\
\text { a little }\end{array}$ & $\begin{array}{l}\text { Like } \\
\text { a lot }\end{array}$ & $\begin{array}{l}\text { Like } \\
\text { a little }\end{array}$ & $\begin{array}{l}\text { Like } \\
\text { a lot }\end{array}$ \\
\hline $\begin{array}{l}\text { Dense coniferous forest; only } \\
\text { opening provided by two } \\
\text { somewhat overgrown fallen } \\
\text { logs in the center }\end{array}$ & 1 & Forest—nature scene & 17.4 & 78.3 & 16.7 & 59.5 & 13.2 & 79.4 \\
\hline $\begin{array}{l}\text { Deciduous forest with } \\
\text { maintained dirt trail curving } \\
\text { through center; trees form } \\
\text { closed canopy }\end{array}$ & 2 & $\begin{array}{l}\text { Forest-nature scene/ } \\
\text { minimal } \\
\text { maintenance }\end{array}$ & 26.1 & 69.6 & 31.0 & 61.9 & 20.9 & 73.1 \\
\hline $\begin{array}{l}\text { Expansive lake with view of } \\
\text { completely forested islands } \\
\text { and inlets; calm blue waters }\end{array}$ & 3 & $\begin{array}{l}\text { Aquatic-nature } \\
\text { scene }\end{array}$ & 4.3 & 89.1 & 11.9 & 83.3 & 7.7 & 89.2 \\
\hline $\begin{array}{l}\text { Rocky outcrop with lighthouse } \\
\text { and buildings, large waves in } \\
\text { foreground, leaves fallen from } \\
\text { some trees, water bluish-green }\end{array}$ & 4 & $\begin{array}{l}\text { Aquatic_built } \\
\text { environment/nature } \\
\text { scene }\end{array}$ & 43.5 & 52.2 & 24.4 & 48.8 & 34.3 & 47.8 \\
\hline $\begin{array}{l}\text { Urban park with skyscrapers } \\
\text { forming the backdrop, treetops } \\
\text { form closed canopy, small } \\
\text { portion of paved trail visible; } \\
\text { pond and building with people } \\
\text { on the deck in the foreground }\end{array}$ & 5 & $\begin{array}{l}\text { Urban park-built } \\
\text { environment/ } \\
\text { buildings }\end{array}$ & 17.4 & 34.8 & 26.2 & 45.2 & 34.3 & 34.3 \\
\hline $\begin{array}{l}\text { Urban park with manicured lawn } \\
\text { visible in foreground and } \\
\text { through trees, large trees in } \\
\text { foreground as well as pergola } \\
\text { with climbing vine, paved } \\
\text { walkway and seating area in } \\
\text { center }\end{array}$ & 6 & $\begin{array}{l}\text { Urban park-built } \\
\text { environment }\end{array}$ & 54.3 & 26.1 & 25.0 & 30.0 & 35.8 & 23.9 \\
\hline $\begin{array}{l}\text { Large alligator basking in the } \\
\text { sun in tall grass; clean, clear, } \\
\text { shallow water in the } \\
\text { foreground }\end{array}$ & 7 & $\begin{array}{l}\text { Wildlife predator- } \\
\text { aquatic nature scene }\end{array}$ & 28.3 & 41.3 & 25.0 & 27.5 & 37.3 & 35.8 \\
\hline $\begin{array}{l}\text { Forested mountain peaks in } \\
\text { background, trees and shrubs } \\
\text { grow to the water's edge, large } \\
\text { fish has jumped several feet } \\
\text { out of the water }\end{array}$ & 8 & $\begin{array}{l}\text { Wildlife_-aquatic } \\
\text { nature scene }\end{array}$ & 15.2 & 76.1 & 12.2 & 65.9 & 9.0 & 85.1 \\
\hline
\end{tabular}

results of the means comparisons for all the pictures). Although noticeably lower number of blacks indicate they like the photograph with the fallen log a lot, it should be noted that $\sim 6$ out of 10 blacks said they like the photograph a lot.

Respondents say they like this photo because the scene is lush, green, beautiful, full of life, evokes peace, looks healthy, shows natural processes, is untamed, unpolluted, pure, pristine, wilderness, mysterious, secluded, clean, seems very quiet, and brings back pleasant memories. A black male writes, "This is what I picture when I think about nature." Another black student said about the scenery:
I'm in love with the green of this photo. I can imagine how overwhelming this landscape would be in person. And I can imagine how tiny and insignificant I might feel in this landscape.

A Hispanic female had a similar response. She writes,

I would feel small being surrounded by such tall trees, but the greenery is calming.

These students are expressing some of the myriad of feelings that courses through one's being when one encounters wild nature. Respondents expressed object-specific dislike in some instances. That is, they demonstrated that one can like aspects of a landscape while disliking other 


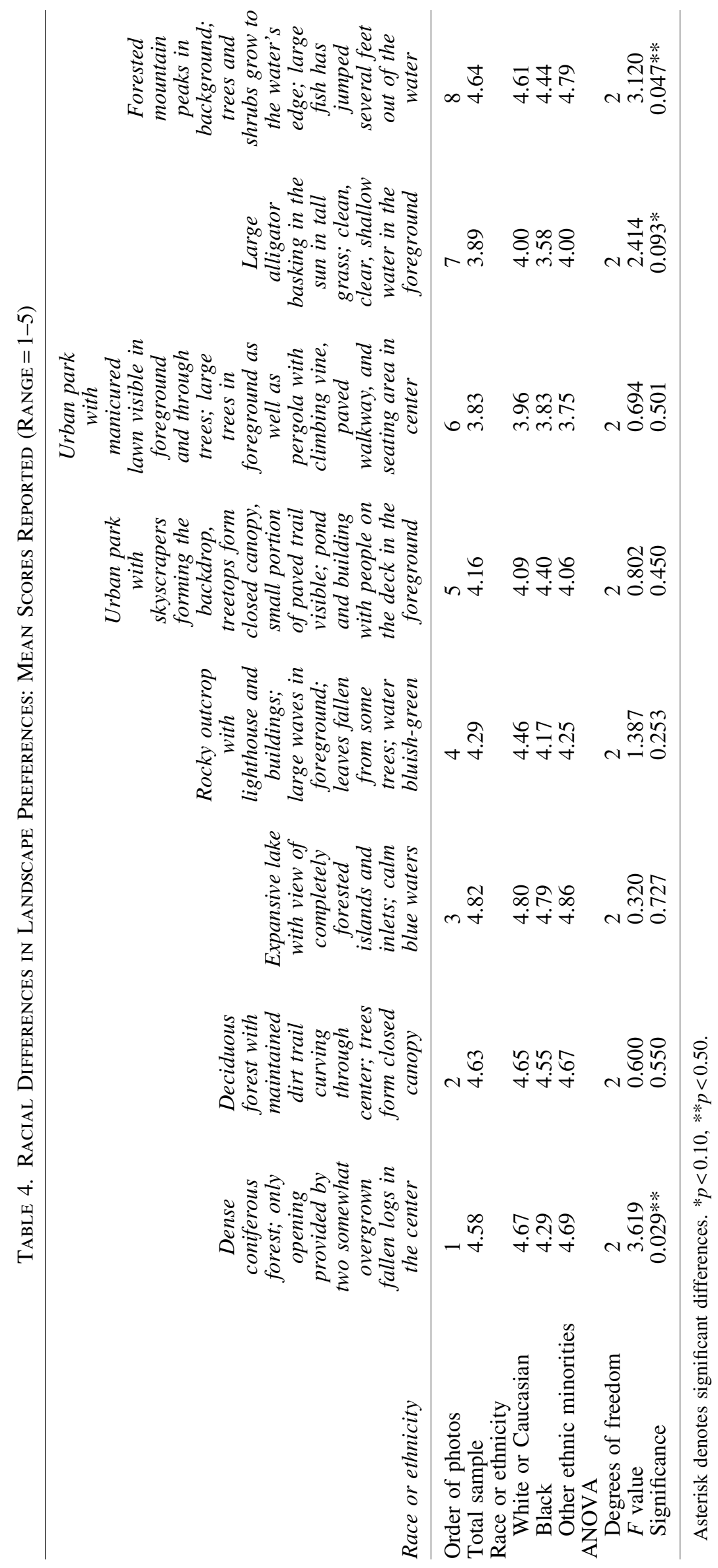


aspects of it. The commentary of an Asian female illustrates this point. She did not like the lack of openness the scene conveyed but she still enjoyed it as "it shows nature's power to be able to take over a piece of land." A white student was somewhat perturbed by the scene because she thought the forest looked "sick" and might be "overrun with invasive species."

The second picture participants saw was one featuring a closed canopy of deciduous trees: a well-maintained dirt trail curved through the center of the photo. Like the forest scene that preceded it, respondents like this scene a lot. Overall, $69 \%$ of the respondents said they like this picture a lot. As was the case with the first forest scene, blacks were less enthusiastic about the photo than either whites or other minorities. Thus, $61.9 \%$ of blacks, $69.6 \%$ of whites, and $73.1 \%$ of other minorities like this image a lot. Other minorities and whites have almost identical mean scores (4.67 and 4.65, respectively), whereas blacks have a mean score of 4.55. The results of the ANOVA show that the differences in the means are insignificant.

Most respondents say they like this landscape because it offers opportunities for active recreation such as walking, hiking, or jogging. Others think it is beautiful and peaceful, they can imagine themselves in the space, and that the trail in the picture reflects minimal disturbance of the landscape. Respondents also think about accessibility for themselves and others when forming opinions about landscapes. So, one participant writes,

Initially I thought the path in the image was wider/more disruptive than necessary, but on second look I considered that a wider, flatter path might make this natural landscape more accessible to people with needs different from my own (e.g., wheelchair users).

Only one respondent is critical of the scene and suggests that it might be too accessible. Although she generally likes the image, she expresses object-specific dislike for one of its features. Thus, she says,

I like it, but I don't love the very flat path that suggests an easy and heavily used walking trail.

Aquatic shoreline scenes. The first of the aquatic scenes shows an expanse of calm blue water with numerous bays, inlets, and islands covered in dense forests. Eighty-eight percent of the respondents like this photograph a lot. An identical percentage of other minorities and whites $(89 \%)$ like this photo a lot; $83.3 \%$ of blacks feel the same way about the image. There is little variation in the way respondents view this photograph: the highest mean score is 4.86 for other minorities; whites and blacks have almost identical mean scores (4.80 and 4.79, respectively).

Study participants say they like the picture because the waters look clean and islands are lush, beautiful, intriguing, and inviting. According to an Asian female,

I feel excited because I can visualize all the wonderful things I could do there.

A biracial/multiracial female writes, the "water is appealing to my soul." The landscape also makes re- spondents think of exploration. For this reason a white male says,

It feels like the edge of the world, land unexplored overlooking a great sea or bay.

Others think about who visits or lives there. A black female notes,

This picture makes me wonder how many people have actually been there... The water seems deep, there is no real "beach" and there seems to be no cutting of trees. I like that it seems that nature exist as just nature here.

A black male adds, this is

Somewhere I wouldn't mind living. [I] think these are volcanic islands, which again is crazy to think how they formed.

The thought of being in or living in the scenery leads a white female to surmise,

It feels unattainable. I know I wouldn't be seeing those islands like that without the help of a plane hoisting me into the air, so the longing for me to actually see all those islands, the beauty of those islands, is suppressed by the realization that I cannot actually put my body there, at least not in that moment, because I am in a plane. This picture is like an appetizer, whetting my appetite and yearning to explore those islands.

The second aquatic picture shows a rocky shoreline on which waves are crashing. A small lighthouse can be seen on a promontory in one corner of the photograph. A few small buildings are also near the lighthouse. Respondents are not as captivated by this scenery as they are by the forested islands nestled in clam waters. Only $49.4 \%$ of the study participants indicate that they like the photograph with the built structures a lot. The total sample mean is 4.29 for this picture. Whites have the highest mean (4.46), whereas blacks have the lowest mean (4.17).

Respondents are conflicted about this photo and express mixed feelings about it. Their comments illustrate the simultaneous contradictions that arise when both positive and negative thoughts about landscape scenes and nature coexist in the same person at the same time. One Native American student thinks of the natural elements and danger as she views the picture. She says,

Well it does look nice but just thinking about tsunamis or storms [that could] hit the area is just scary.

An Asian male agrees. To him the landscape is "beautiful but dangerous." A biracial/multiracial female thinks that, "The ocean crashing in is majestic but the cliff is very rocky and less appealing," while a biracial/ multiracial male says,

The lighthouse and cliff are both very scenic. However, it seems that coastal development has contributed to the erosion along the shoreline.

Generally speaking, respondents like the beauty of the scene and the clean water. They also say it is peaceful, it is reminiscent of home, it prompts one to think about being in the space, and that the juxtaposition of the topography is interesting. However, some dislike the photo 
because the landscape looks barren, the cliffs are bare, the deciduous trees have no foliage, and it looks cold. In this vein, a white male respondent links his dislike of the scenery to his dislike of a sports team. He explains that

The trees are dead, which reminds me of winter. This scene reminds me of New England and I don't like the Patriots.

Urban park scenery. Respondents were shown two pictures of large urban parks. The urban park scenes are among the least favorite for study participants. The first picture-liked a lot by $37.4 \%$ of the participants-depicts a park with numerous skyscrapers in the background. Treetops are visible in the center of the picture while a pond with a barely visible paved trail is in the foreground. Also in the foreground is a building with people on the deck. Although $34.3 \%$ of other minorities and $34.8 \%$ of whites like this scene a lot, $45.2 \%$ of black feel similarly. Although blacks are more likely to like this picture a lot than whites and other minorities, less than half of the black respondents say they like this picture a lot.

Despite the plethora of studies already cited that report that blacks prefer manicured urban park settings to wild and naturalistic landscapes, blacks were not drawn to the picture en masse. Black respondents dislike it because it was not appealing, and study participants did not like to see the city in the background. As one black female student puts it,

The park looks very cramped and the city in the background makes it seem noisy.

Blacks who like the photograph say, "I like that there is forest cover even in a place like NYC [New York City]," and that

This photo shows a beautiful dichotomy of the natural (a cluster of trees) and the built (a cluster of tall buildings) environment. The separation is interesting and stark in this photo.

They also like the image because it is familiar and reminiscent of home, and it shows an attempt to preserve green space in a city. Other respondents had similar perceptions of the picture. For instance, a Native American female thinks the city detracts from the park, whereas a second believes that

The trees are pretty but the background of tall buildings makes me sad because of pollution and [the] taking [and] over cutting our trees and forests.

A Native American male also sees both positives and negatives in the scene. He writes,

The trees seem a bit homogenous and I'm sure pollution isn't great there, but pretty nonetheless.

Relatively few black participants like the second park picture a lot-only $30 \%$ of them do. An even lower percentage of other respondents do- $-26.1 \%$ of whites and $23.9 \%$ of other minorities say they like the picture a lot. The picture portrays an expansive urban park with ample manicured lawn; large widely spaced trees frame the picture in the background and fore. The foreground also features a pergola with a lush climbing flowering vine, seating areas, and a paved walkway. The ANOVA shows that the racial differences in mean scores are statistically insignificant.

Blacks are not very enthusiastic about this landscape. A black male says, it "just looks like a regular park. Nothing special," whereas a black female notes that "It's nice but not AMAZING." Another thinks it is "too urbanized," whereas yet another says,

I'm a very practical minded person. I look at scenes and imagine what I would do in them. I can't picture myself doing anything in this other than sitting on the wall.

However, a black female who likes the park writes,

I like going to parks because it's my only escape to nature since I live in the city.

Other blacks think the park is peaceful, the greenery is nice, and it would be "nice for a wedding." Hispanic students had similar reactions to the image. Henceforth, a Hispanic female exclaims,

Nothing special in perspective. Shows the combination of nature and our effects on it, by hiding within it.

Another Hispanic female thinks the scene reflects "a destruction of nature [to] rebuild...something natur[al]." A Hispanic male explains that the plants in the park scene

Reminds me of an invasive vine (wisteria), potentially, on top of the archway-which is beguiling and horrifying at the same time.

Wildlife scenes. The first of the two wildlife pictures feature an alligator sunning in the tall grass abutting clean, clear, shallow water. In general, $35.3 \%$ of the respondents say they like this photograph a lot. Although $41.3 \%$ of whites and $35.8 \%$ of other minorities like this picture a lot, only $27.5 \%$ of blacks feel this way about the picture. A comparison of means shows that whites and other minorities an identical mean of 4.0. In contrast, blacks have a mean of 3.58. ANOVA reveals that the differences in the means are significant $(F=2.414$, $p=0.093$ ).

Some blacks as well as other respondents use the words fear, scary, and danger to describe the alligator visible in this image. Respondents focused on objectspecific dislikes rather than the background scenery. One black student was ambivalent about the picture. She says, "I'm not super interested in alligators, but spotting awesome organisms is super cool." Another is also ambivalent. To him,

Animals are essential to nature, and while I do not particularly love looking at crocodiles, I understand their importance to their particular niche.

Others express their fears and anxiety more openly. A black female says, "I would not want to be here; seems to be a dangerous situation." Another concurs. 
Gators are dangerous, but just let them be and they'll extend you the same courtesy. I do not want to be bitten so I do not like the image, but I also would not be caught by the gator, so I do not dislike it.

Black students write about keeping their distance; one says,

I think it is a great photo of wildlife. However, I would not want to be too close to [the] main subject.

Nonetheless, there is one black female respondent who says, "I love Alligators!" and another who declares, "It's beautiful." The responses of these two black females are analogous to that of the white female who notes, "That's a really cool and majestic creature."

The second wildlife photograph features a large invasive fish jumping high out of the water. The center of the picture comprises trees and thick shrubs. Distant mountains form the background. Most respondents (77.3\%) say they like this picture a lot. A comparison of means show that other minorities have a mean of 4.79 , whites a mean of 4.61, and blacks a mean of 4.44. Results from the ANOVA procedure shows that the differences in the means are significant $(F=3.120, p=0.047)$.

The fish stole the show. Respondents like this image because the fish is "in his element," the image evokes memories of fishing, the flight of the fish is intriguing, the water looks healthy and sustains life, and the landscape is beautiful. Respondents also like the freedom suggested by the fish, the landscape looks peaceful, and makes people happy. Respondents did not articulate any dislikes for the image, but one notes that "I would not be as likely to go in the water with such fish in the water." Another cautions the fish, "Jump! Before the humans can catch you and eat you for dinner!"

Variations in the ranking of the scenes. When the whole sample was considered, respondents rank the chain of forested islands highest followed by the large fish jumping out of the water, and the forest with the maintained trail. The coniferous forest scene with the fallen logs is ranked fourth, shoreline with crashing waves and light house is ranked fifth, the urban park with the pond, sixth, the alligator lying in the grass is ranked seventh, and the urban park with manicured lawn is the least favored picture.

There is some consistency in the ranking of pictures. All the groups being studied gave the forested chain of islands the highest ranking. Although non-whites ranked the picture of large fish jumping out of the water among their top three favorite scenes, whites rank this picture as their fourth highest. Whereas blacks give the picture of the urban park with the manicured lawns visible between the trees the second lowest ranking, whites and other minorities rank it lowest. Blacks rank the picture with the alligator as their least favored image.

Although the scholarly literature leads one to predict that blacks would rank the pictures differently from whites and other ethnic minority groups depending on whether they have urban scenes, built environments, or natural and wild scenes in them, this is not the case.
Blacks rank the two urban park scenes fourth and seventh overall. They rank the chain of forested islands first, and the other forest scenes second and fifth. Their least favorite photograph is the one with the wildlife predatorthe alligator-featured prominently in the picture.

\section{The relationship between landscape preferences, connectedness to nature, and curiosity about nature}

There is a relationship between connectedness to nature and landscape preferences (Table 5). In general, the more connected respondents say they are to nature, the more likely they are to say they like the landscape scenes. This is particularly true of the naturalistic landscapes. Whites who feel very connected to nature gave the urban park scene with the skyscrapers significantly lower scores than all other respondents. But all the black students who say they are very connected to nature gave this image a score of 5. Overall, respondents who are very curious about nature tend to give the naturalistic images higher scores than those who describe themselves as merely curious.

\section{DISCUSSION AND CONCLUSIONS}

Several researchers report that blacks prefer open, developed, urban, managed scenery over wild, undisturbed or minimally disturbed, and wooded scenery. ${ }^{98,99,100,101,102,103,104,105,106}$ But the findings of this study do not support the results of these earlier studies. This study shows that similar percentages of black and white students think first and foremost about trees, forests, and plants when they think of nature. Other ethnic minority students also think of trees, forests, and plants most frequently when they think of nature. Black students also think of peace, tranquility, and spirituality when they contemplate nature. Although a small percentage of blacks reflect on man-made hazards when thinking of nature, none say they focus on urban environments when they think of nature.

Like whites and other minorities, black college students in this study tend to prefer naturalistic landscapes over urbanized and managed landscapes. For the most part, the landscape preferences of black students did not differ significantly from that of whites or other ethnic minority groups. The ANOVA results show that differences were significant for only three of the eight images that respondents viewed.

Although Johnson ${ }^{107}$ and Lewis and Hendricks ${ }^{108}$ contend that blacks are alienated from nature and some

\footnotetext{
${ }^{98}$ Talbot and Kaplan, Op. cit.

${ }^{99}$ Zube, et al., Op. cit.

${ }^{100}$ Peterson, $O p$. cit.

${ }^{101}$ Anderson, $O p$. cit

${ }^{102}$ Zube and Pitt, Op. cit.

${ }^{103}$ Kielbaso, Op. cit.

${ }^{104}$ Medina, Op. cit.

${ }^{105}$ Virden and Walker, $O p$. cit.

${ }^{106}$ Gramann, Op. cit.

${ }^{107}$ Johnson, Op. cit.

${ }^{108}$ Lewis and Hendricks, Op. cit.
} 
Table 5. The Relationship Between Connectedness to Nature and the Extent to Which Respondents LiKe Landscape ScEnes

\begin{tabular}{|c|c|c|c|c|c|}
\hline \multirow[b]{2}{*}{ Description of landscape scenes } & \multirow{2}{*}{$\begin{array}{l}\text { Feelings of } \\
\text { connectedness } \\
\text { to nature }\end{array}$} & \multicolumn{4}{|c|}{ Mean score (range 1-5) } \\
\hline & & $\begin{array}{l}\text { Total } \\
\text { sample }\end{array}$ & White & Black & $\begin{array}{l}\text { Other } \\
\text { minorities }\end{array}$ \\
\hline \multirow{2}{*}{$\begin{array}{l}\text { Coniferous forest with fallen } \\
\operatorname{logs}\end{array}$} & Connected & 4.55 & 4.65 & 4.27 & 4.73 \\
\hline & Very connected & 4.69 & 4.71 & 4.44 & 4.76 \\
\hline \multirow[t]{2}{*}{ Deciduous forest with trail } & Connected & 4.58 & 4.65 & 4.50 & 4.61 \\
\hline & Very connected & 4.69 & 4.67 & 4.56 & 4.75 \\
\hline \multirow{2}{*}{ Forested chain of islands } & Connected & 4.72 & 4.61 & 4.73 & 4.79 \\
\hline & Very connected & 4.95 & 5.00 & 4.89 & 4.92 \\
\hline \multirow[t]{2}{*}{ Rocky outcrop with lighthouse } & Connected & 4.19 & 4.35 & 4.03 & 4.21 \\
\hline & Very connected & 4.45 & 4.62 & 4.44 & 4.32 \\
\hline \multirow[t]{2}{*}{ Urban park with skyscrapers } & Connected & 4.12 & 4.26 & 4.20 & 3.94 \\
\hline & Very connected & 4.19 & 3.76 & 5.00 & 4.25 \\
\hline \multirow[t]{2}{*}{ Urban park with pergola } & Connected & 3.77 & 3.83 & 3.73 & 3.76 \\
\hline & Very connected & 3.96 & 4.10 & 4.38 & 3.75 \\
\hline \multirow[t]{2}{*}{ Wildlife predator at water's edge } & Connected & 3.65 & 3.70 & 3.40 & 3.82 \\
\hline & Very connected & 4.32 & 4.48 & 4.50 & 4.14 \\
\hline \multirow{3}{*}{$\begin{array}{l}\text { Wildlife-fish leaping out of } \\
\text { water }\end{array}$} & Connected & 4.50 & 4.48 & 4.40 & 4.61 \\
\hline & Very connected & 4.84 & 4.76 & 4.67 & 4.96 \\
\hline & $\begin{array}{c}\text { Curiosity about } \\
\text { nature }\end{array}$ & & & & \\
\hline \multirow{2}{*}{$\begin{array}{l}\text { Coniferous forest with fallen } \\
\operatorname{logs}\end{array}$} & Curious & 4.39 & 4.27 & 4.21 & 4.82 \\
\hline & Very curious & 4.68 & 4.79 & 4.45 & 4.70 \\
\hline \multirow[t]{2}{*}{ Deciduous forest with trail } & Curious & 4.56 & 4.55 & 4.58 & 4.55 \\
\hline & Very curious & 4.68 & 4.71 & 4.55 & 4.73 \\
\hline \multirow[t]{2}{*}{ Forested chain of islands } & Curious & 4.71 & 4.45 & 4.79 & 4.82 \\
\hline & Very curious & 4.90 & 4.97 & 4.86 & 4.87 \\
\hline \multirow[t]{2}{*}{ Rocky outcrop with lighthouse } & Curious & 4.05 & 4.09 & 4.05 & 4.00 \\
\hline & Very curious & 4.42 & 4.59 & 4.38 & 4.33 \\
\hline \multirow[t]{2}{*}{ Urban park with skyscrapers } & Curious & 4.37 & 4.27 & 4.68 & 3.91 \\
\hline & Very curious & 4.14 & 4.12 & 4.32 & 4.07 \\
\hline \multirow[t]{2}{*}{ Urban park with pergola } & Curious & 3.68 & 3.55 & 3.72 & 3.73 \\
\hline & Very curious & 3.89 & 4.06 & 3.95 & 3.76 \\
\hline \multirow[t]{2}{*}{ Wildlife predator at water's edge } & Curious & 3.35 & 3.18 & 3.33 & 3.55 \\
\hline & Very curious & 4.10 & 4.26 & 3.81 & 4.11 \\
\hline \multirow{2}{*}{$\begin{array}{l}\text { Wildlife-fish leaping out of } \\
\text { water }\end{array}$} & Curious & 4.33 & 4.18 & 4.28 & 4.55 \\
\hline & Very curious & 4.79 & 4.82 & 4.64 & 4.84 \\
\hline
\end{tabular}

such as Kellert ${ }^{109}$ and Schroeder ${ }^{110}$ conclude that blacks are less likely to be oriented toward nature than whites, the findings of this study suggest otherwise. None of the black students in this study report that they are somewhat or very disconnected from nature, neither did any other students. Moreover, the vast majority of black respondents say that they are somewhat or very curious about nature. Again, this is similar to the percentages of other students who indicate that they are somewhat or very curious about nature.

If scholars are interested in theorizing and measuring connectedness to nature, then it is incumbent upon them to develop accurate and reliable ways of measuring this construct. Although Mayer and Frantz ${ }^{111}$ contend that

\footnotetext{
${ }^{109}$ Kellert, Op. cit.

${ }^{110}$ Schroeder (1990), Op. cit.

${ }^{111}$ Mayer and Frantz, Op. cit.
}

their connectedness-to-nature scale measures emotional connections to the natural world, Perrin and Benassi ${ }^{112}$ argue that the scale does not. Instead of emotional connections to nature, the Mayer-Frantz scale measures cognitive beliefs. This is important as the Mayer-Frantz scale is widely cited in studies purporting to test connectedness to nature.

Researchers also report that blacks are fearful of wild landscapes ${ }^{113,114,115,116,117,118}$ and find them repulsive. ${ }^{119}$

\footnotetext{
${ }^{112}$ Perrin and Benassi, Op. cit.

${ }^{113}$ Talbot and Kaplan, Op. cit.

${ }^{114}$ Bixler, et al., Op. cit.

${ }^{115}$ Floyd, et al., Op. cit.

${ }^{116}$ Gobster, Op. cit.

${ }^{117}$ Brownlow, Op. cit.

${ }^{118}$ Lewis and Hendricks, Op. cit.

${ }^{119}$ Bixler and Floyd, Op. cit.
} 
Instead of the generalized fear of the environment reported in earlier studies, this study found that the fear students express is situational. Expressing situational fear was not unique to blacks - that is, students from all racial backgrounds expressed fear in particular situations. The study also found that participants expressed multiple and conflicting responses to a given landscape simultaneously. None of the study participants articulated a generalized fear of the landscapes they were shown. However, when explaining why they dislike the photographs, some students express situational fear. This is the case for the photograph depicting the alligator. This picture evoked situational fear, object-specific dislike, and simultaneous contradictions. It was one of the least favorite pictures of the respondents. Some students from each racial group said they were fearful of the alligator. None generalized their fear to all animals, to all wild landscapes, or to nature writ large.

Fear is an interesting dimension of nature and environmental experiences to interrogate. Since the nineteenth century, nature lovers and environmental advocates have extolled the virtues of sublime landscapes as part of Romanticism and the transition toward focusing on environmental protection in America. Among other things, sublime landscapes evoke fear - this is part of the aura and mystique of such places. The diaries and writings of renowned environmental leader, Henry David Thoreau, reveal that he was overcome by fear when he hiked to the top of Mount Kathadin in Maine. John Muir also discusses the fears he experienced in Yosemite and Hetch Hetchy in California. ${ }^{120,121}$ But, no one would consider these men and others like them to be generally fearful of nature, biophobic, or alienated from nature because they experienced and expressed fear in particular situations and spaces.

Researchers often mischaracterize fears expressed by blacks because they do not embed their discussion of blacks and fear of nature in the larger context of American Romanticism and Transcendentalism. Around the time Henry David Thoreau, John Muir, and other early white middle-class male and female environmental advocates were exploring the wilderness, a run-away slave, Harriet Tubman, described how she lay out in the woods all night till fear enveloped her body. In this heightened state of excitement, she felt very connected to the woods and she could absorb the knowledge that nature provided her. She used these transcendental experiences to instruct her on how to interpret the landscape, carry out raids, and guide slaves on arduous journeys to freedom. ${ }^{122}$

In many of the discussions about blacks and their relationship to nature, these nuanced contexts are missing. Fear as an important element of environmental awakening and understanding is missing from the dis-

\footnotetext{
${ }^{120} \mathrm{Nash}$, Op. cit.

${ }^{121}$ Taylor (2016), Op. cit.

${ }^{122}$ Ibid.
}

cussion of connectedness to nature. Moreover, fear, as experienced by blacks, is often construed in largely negative terms. As a result, if blacks express fear in their interactions with the natural world, it is often framed as an aberration, deviance, alienation, ignorance, and in negative terms. It is also generalized to describe all or most interactions and to all or most blacks. ${ }^{123,124,125,126,127,128,129}$ This rises to the level of stereotypes. Although other racial and ethnic minorities and whites express fear for nature at times, the fear is not usually reported as a generalized emotion that inhibits interaction with nature.

Despite Shinew et al.'s ${ }^{130}$ and Vasi's ${ }^{131}$ articles that found significant class differences in recreational behavior, researchers still tend to ignore class differences and other factors such as immigration status and culture that can affect perceptions of nature. The findings already presented suggest that researchers such as Stamps and Stamps ${ }^{132}$ may be grossly underestimating class differences when it comes to understanding the attitudes and perceptions of blacks and other racial groups. The findings of this study suggest that not all blacks are alike in the way they perceive nature, but the sample of black college students studied think about and have connections to nature in ways that differ from what has been reported in past studies. Some exhibit the mindbody-spirit connections to nature that Zylstra et al. ${ }^{133}$ described.

The findings presented here also imply that education levels matter. The college-educated blacks in this sample did not articulate thoughts about nature, or exhibit levels of connectedness to nature, or landscape preferences that were aberrant. Blacks were similar to other minorities as well as to whites in many ways in their perceptions about nature and landscapes. Although Virden and Walker ${ }^{134}$ studied college students and concluded that white and Hispanic students had greater preferences for remote and less developed spaces than blacks and that white students found the forests to be safer than either blacks or Hispanics, these findings were not supported by the data presented in this study. These differences in results could arise because the methodological approaches differ and the college students in Virden and Walker's sample all came from one university campus. The findings already presented come from students who attend different colleges. This allows for a broader array of experiences and perceptions to inform the study.

\footnotetext{
${ }^{123}$ Talbot and Kaplan, Op. cit.

${ }^{124}$ Bixler, et al., Op. cit.

${ }^{125}$ Floyd, et al., Op. cit.

${ }^{126}$ Gobster, Op. cit.

${ }^{127}$ Brownlow, Op. cit.

${ }^{128}$ Lewis and Hendricks, Op. cit.

${ }^{129}$ Bixler and Floyd, Op. cit.

${ }^{130}$ Shinew, et al., Op. cit.

${ }^{131}$ Vasi, Op. cit.

${ }^{132}$ Stamps and Stamps, Op. cit.

${ }^{133}$ Zylstra, et al., Op. cit.

${ }^{134}$ Virden and Walker, Op. cit.
} 
Future research in this field should investigate how race, gender, age, class, and educational attainment intersect to influence perceptions of nature, connectedness to it, and landscape preferences. This should be done with a large sample. Researchers undertaking this research should be sensitive to the ways in which social factors influence access to nature and perceptions of it. Those sensitivities should also be incorporated into the investigation. Curiosity about nature should be interrogated too. That is, does curiosity about nature result in different perceptions and behavioral outcomes than connectedness to nature? Future research should also provide greater opportunities for respondents to reflect on and explain their perceptions of nature as these reflections provide important insights into the ways in which respondents view and interact with nature.

\section{ACKNOWLEDGMENTS}

This research was supported by the University of Michigan, the C.S. Mott Foundation, and the Doris Duke Charitable Foundation.

\section{AUTHOR DISCLOSURE STATEMENT}

No competing financial interests exist.

Address correspondence to:

Dorceta E. Taylor

School for the Environment and Sustainability

University of Michigan

440 Church Street

Ann Arbor, MI 48109-1115

E-mail: dorceta@umich.edu 